\title{
Condyloma acuminatum: its histopathological pattern
}

\author{
Realized at Antônio Pedro University Hospital, Department of Pathology,
} Universidade Federal Fluminense - Niterói, Brazil.

\begin{abstract}
Condyloma acuminatum is one of the clinical manifestations of papillomavirus infection. The classical histopathological features are already known and do not constitute a diagnostic problem. Clinically, it has been classified into growth or proliferative, full-expression, and regressive or persistent phases, with the histopathological aspects of these distinct phases being well documented in equine cutaneous papillomas. We have designed a protocol of histopathological analysis in order to investigate the possibility of identifying the evolutional phases in human condylomata acuminata. Sixty condylomata acuminata from the files of the Department of Pathology, Universidade Federal Fluminense, were studied regarding koilocytosis, paraceratosis, acantosis, basal cell hyperplasia and mononuclear cell infiltrate. After an individual analysis and comparison of the cases, the main differential aspects of condyloma acuminatum were: koilocytosis, transepithelial lymphocytic infiltrate and basal cell hyperplasia. Thus, condylomatous lesions can be histopathologically differentiated in three major patterns: proliferative, viral replication activity and regressive.
\end{abstract}

UNITERMS: Condyloma acuminatum, koilocytosis, histopathologic pattern, regression.

\section{INTRODUCTION}

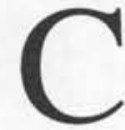

ondyloma acuminatum represents one of the many clinical manifestations of the Human Papillomavirus infection (HPV); it is found more frequently in the genital region and rarely in mucous membranes. ${ }^{1-3}$ Frequently associated with HPV 6 and 11 , the incubation period ranges from 3 weeks to 8 months and occurs particularly in young individuals. ${ }^{1.3}$ Principal clinical consequences are transmission to sexual partners and to the fetus and newborn by infected mothers, and the risk of developing squamous cell carcinoma. ${ }^{3-5}$ Untreated lesions can remain unchanged for 10 or more years, or more rarely, may regress spontaneously. ${ }^{2}$

\section{Address for correspondence: \\ Eliane Pedra Dias}

Rua Br. de Itapagipe, $401 \mathrm{Bl} .2$ Apt. 20

Rio de Janeiro/RJ - Brasil - CEP 20261-000
Classical histopathological features of Condyloma acuminatum were recognized long ago, and are characterized by acantosis, papillomatosis, hyperceratosis, paraceratosis and koilocytosis. ${ }^{6-8}$ Many studies have described its clinical aspects and a great variety of lesions. Different clinical classifications have already been proposed by many authors, but none have been able to correlate the clinical with the histopathological aspects. ${ }^{3.9 .10}$

The analysis of several biopsies from outpatient clinics in gynecology and sexual transmitted diseases (STD) allowed us to observe the differences, both quantitative and qualitative, in the various condylomata acuminata. The growth phase, the full-expression phase, and the regressive or persistent phase have been well characterized clinically. ${ }^{9}$ These phases were recognized histopathologically in equine cutaneous papillomas by HAMADA et al." There have been no similar studies in humans. Therefore, in order to identify their differences and similarities and classify the histopathological evolutionary phases of condylomata acuminata, it is necessary to conduct a histopathological study. 
Among the great number of clinical lesions associated with papillomavirus infection, only flat warts present the characteristics of spontaneous regression. Many reports have attempted to explain this phenomenon, ${ }^{12-16}$ and most of them concur that cell-mediated immunity is responsible for the effective regression of this kind of lesion. This immune response is expressed by an early infiltration of macrophages and $\mathrm{T}$ lymphocytes CD4+ in the dermis and later transepithelial. The non-regressing warts have an inconspicuous infiltrate composed of $\mathrm{T}$ lymphocytes CD $8+{ }^{17}$

In 1993, OKABAYASHI et al. ${ }^{18}$ using rabbits, classified the lesions as proliferative (marked cellular proliferation) and regressive (inflammatory mononuclear cell infiltrate dermal and transepithelial). In 1994, COLEMAN et al. published their first study on the regression of genital warts in closely monitored patients. The main histopathological feature identified by COLEMAN et al. was a marked, continuous subepithelial inflammatory infiltrate, with prominent dermal infiltration.

Based on random observations and studies on the regression phenomenon causing papillomavirus lesions, we have designed a protocol to histopathologically analyze the condylomata acuminata, aiming to identify its evolutionary phases.

\section{MATERIALS AND METHODS}

We retrospectively studied 60 condylomata acuminata from the files of the Department of Pathology (UFF) from January 1994 through April 1996. The selected 60 cases fulfilled the following requirements: a) specimens measuring not less than 0.5 $\mathrm{cm}$ in length and with sufficient dermis; and b) specimens not displaying acute inflammation.

The specimens were stained by the H.E. technique and analyzed as to the classical histopathological aspects considered characteristic of condyloma acuminatum.
The parameters investigated in the epithelium were: koilocytosis (according to MEISELS ${ }^{6}$ ), basal cell hyperplasia (four or more layers of basal cells), acantosis, hyperceratosis, and paraceratosis. Histological evaluation of the dermis included the presence and localization (dermal, basal epithelial, transepithelial) of mononuclear cell infiltrate. The investigation revealed extremely high levels of variation in paraceratosis and mononuclear cell infiltrate, and this resulted in further classification according to intensity, being low, medium and high as follows:

Paraceratosis low: condyloma with few areas of paraceratosis in the epithelium.

Paraceratosis medium: condyloma with some areas of paraceratosis in the epithelium.

Paraceratosis high: condyloma with paraceratosis throughout the epithelium.

Mononuclear cell infiltrate low: condyloma with few lymphocytes and histiocytes in few areas.

Mononuclear cell infiltrate medium: condyloma with lymphocytes and histiocytes, with moderate distribution, sometimes in foci or in a bandlike pattern.

Mononuclear cell infiltrate high: condyloma with intense lymphocytes and histiocytes infiltrate, many times in a band-like pattern.

After individual analysis, the cases were grouped according to their differences and similarities in an attempt to establish an evolutionary classification.

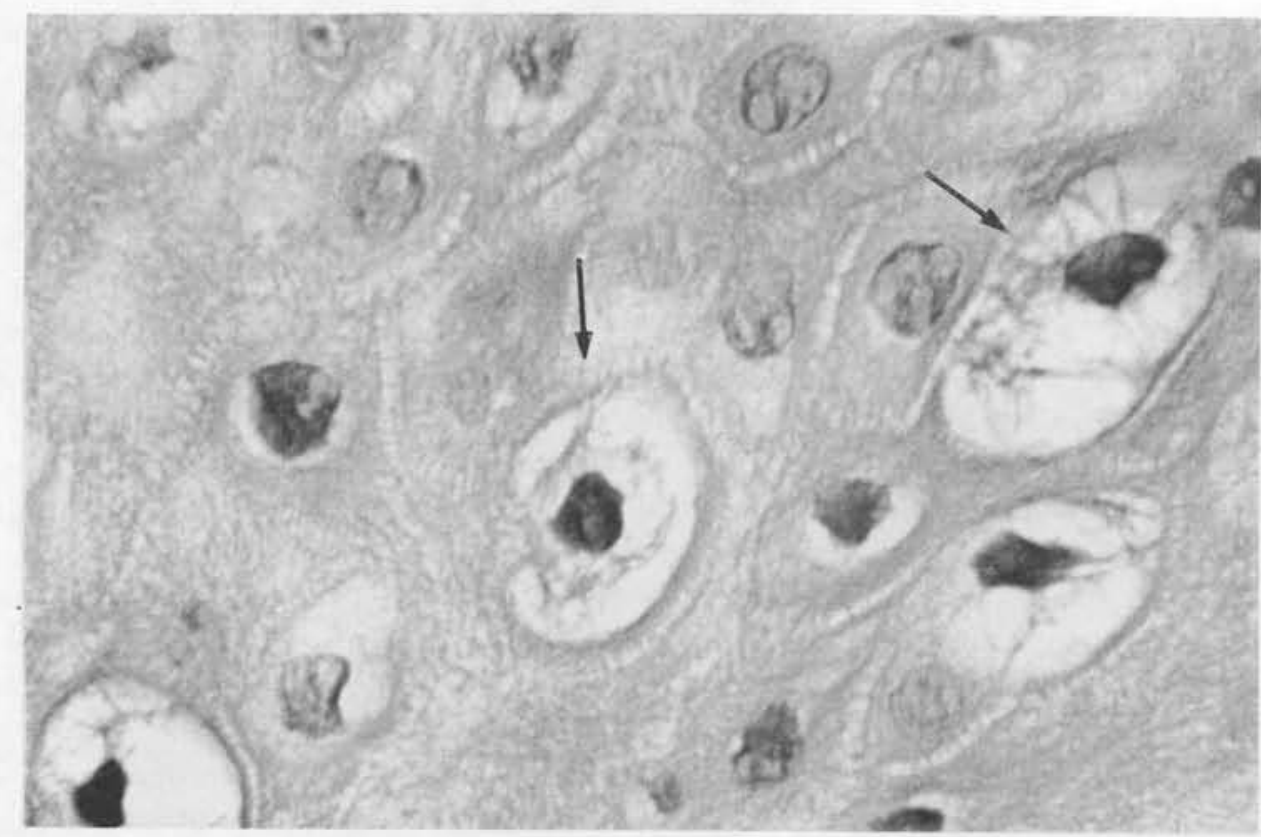

Figure 1 - KOILOCYTOSIS (®) criteria for the classification of condylomata acuminatum as VIRAL REPLICATION ACTIVITY PHASE (Hematoxilina \& Eosina Objective $100 \times$ Ocular $10 \mathrm{x}$ ). 


\section{RESULTS}

The histopathological analysis of the 60 condylomata acuminata showed that koilocytosis and the mononuclear inflammatory infiltration presented the most prominent quantitative differences.

First, we selected the cases where koilocytosis - the histopathological marker of the cytopathic effect of HPV replication-was present. The koilocytosis intensity varies from rare to very numerous and this variation was considered as an evolutionary variation.

Group A was formed by 16 condylomata in which more than five koilocytosis (Fig.1) per section were visible.

From the other 44 cases, for our purposes Group B, we selected 19 condylomas in which the transepithelial inflammatory infiltrate (Fig. 2) - histopathological marker of regression phenomenon - was the most prominent feature.

Group $\mathrm{C}$ was formed by 12 condylomas in which the inflammatory infiltrate was absent or mild and confined

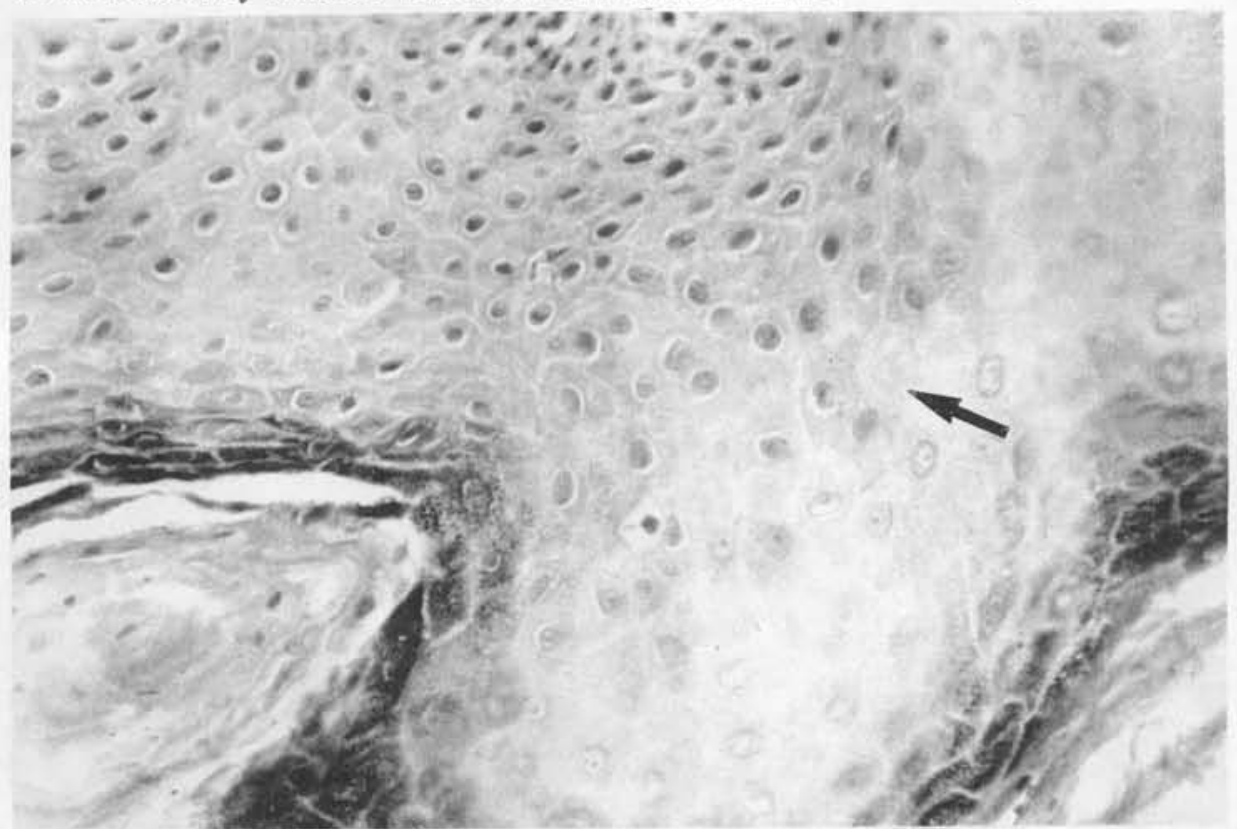

Figura 3: ABSENCE of KOILOCYTOSIS and TRANSEPITHELIAL LYMPHOCYTIC INFILTRATE (囚), criteria for the classification of condylomata acuminatum as PROLIFERATIVE PHASE. (Hematoxilina \& Eosina Objetiva $40 \times$ Ocular $10 \mathrm{x}$ ). to the dermis and the koilocytosis; when present, it was in a concentration of five or less (Fig. 3).

Thus, according to the predominant characteristics, such as koilocytosis, transepithelial mononuclear cell inflammatory infiltrate or transepithelial inflammatory infiltrate and the absence of koilocytosis, the cases were further separated in groups A, B and C respectively. The remaining 13 lesions did not meet any of the criteria and therefore were considered as belonging to an intermediate evolutionary phase and excluded from the study.

\section{GROUP A $(n=16)$}

The detailed histopathological analysis of the cases (Fig. 4) showed acantosis, hyperceratosis and paraceratosis in all cases, and basal cell hyperplasia in 4 ( 25 percent). Paraceratosis was considered mild or moderate in 25 percent of the cases and intense in 50 percent. The lymphocytic inflammatory infiltrate was seen in all cases (mild in 69 and moderate in 31 percent). Dermis and the base of the epithelium were 


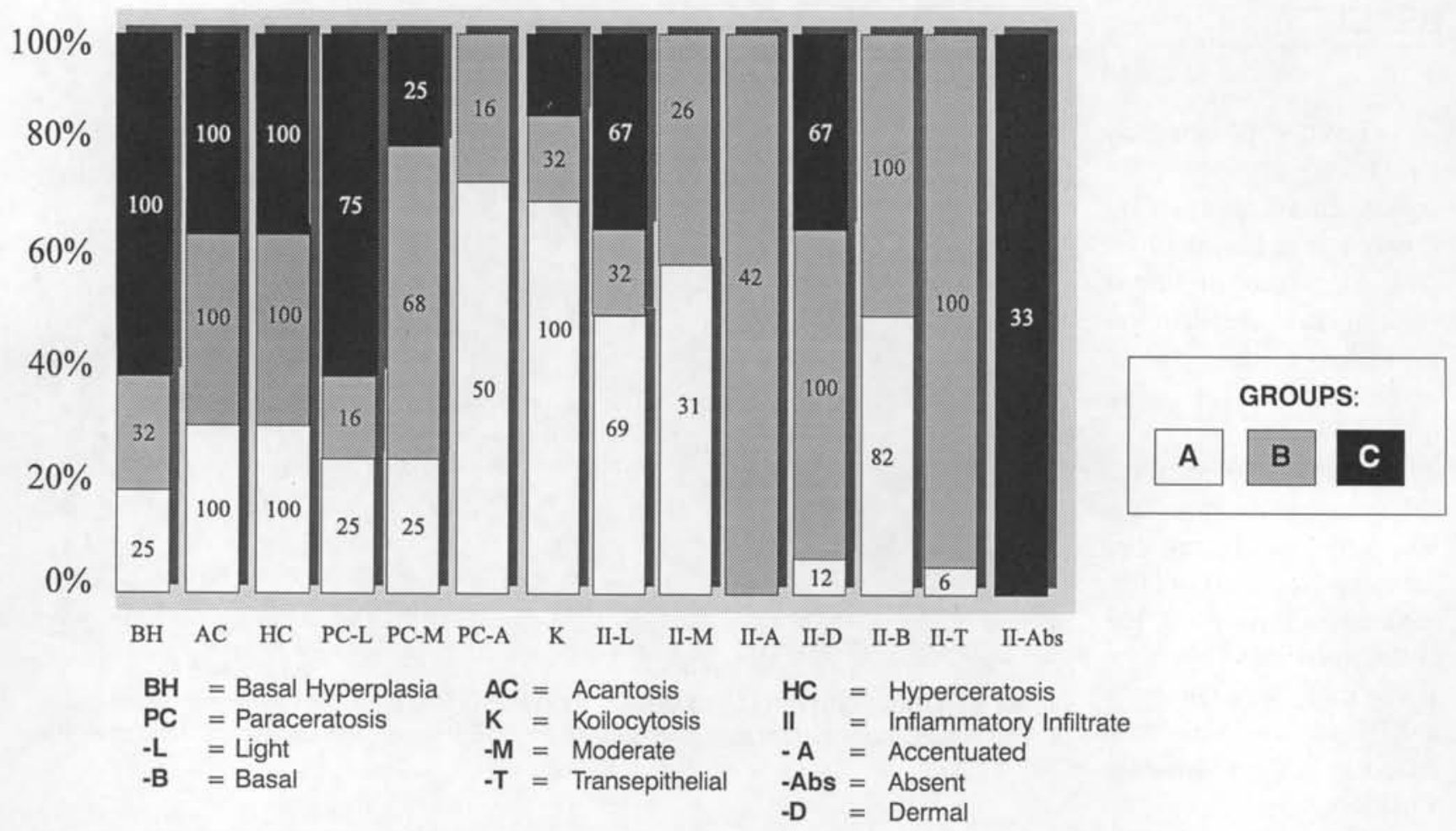

Figure 4 - Percentages relative to the various histopathological aspects identified in:

the most frequent localization ( 88 percent). This group was considered as having the viral replication activity (VRA) pattern (Fig. 5).

\section{GROUP B $(n=19)$}

In this group, (Fig. 4) basal cell hyperplasia was detected in 32 percent. Acantosis, hyperceratosis and paraceratosis were observed in all cases. Paraceratosis was mild in 16 percent, moderate in 68 percent and intense in 16 percent. Koilocytosis was rarely seen ( 6 cases $/ 32$ percent). The mononuclear cell inflammatory infiltrate was localized in the dermis and epidermis, and considered mild in 32 percent, moderate in 26 percent and intense in 42 percent. This was classified as Regressive (R) pattern (Fig. 6).

\section{GROUPC ( $n=22)$}

In this group, both transepithelial inflammatory infiltrate and koilocytosis were rarely seen or were absent. The histopathological analysis of this group (Fig. 4) has displayed basal cell hyperplasia, acantosis, hyperceratosis

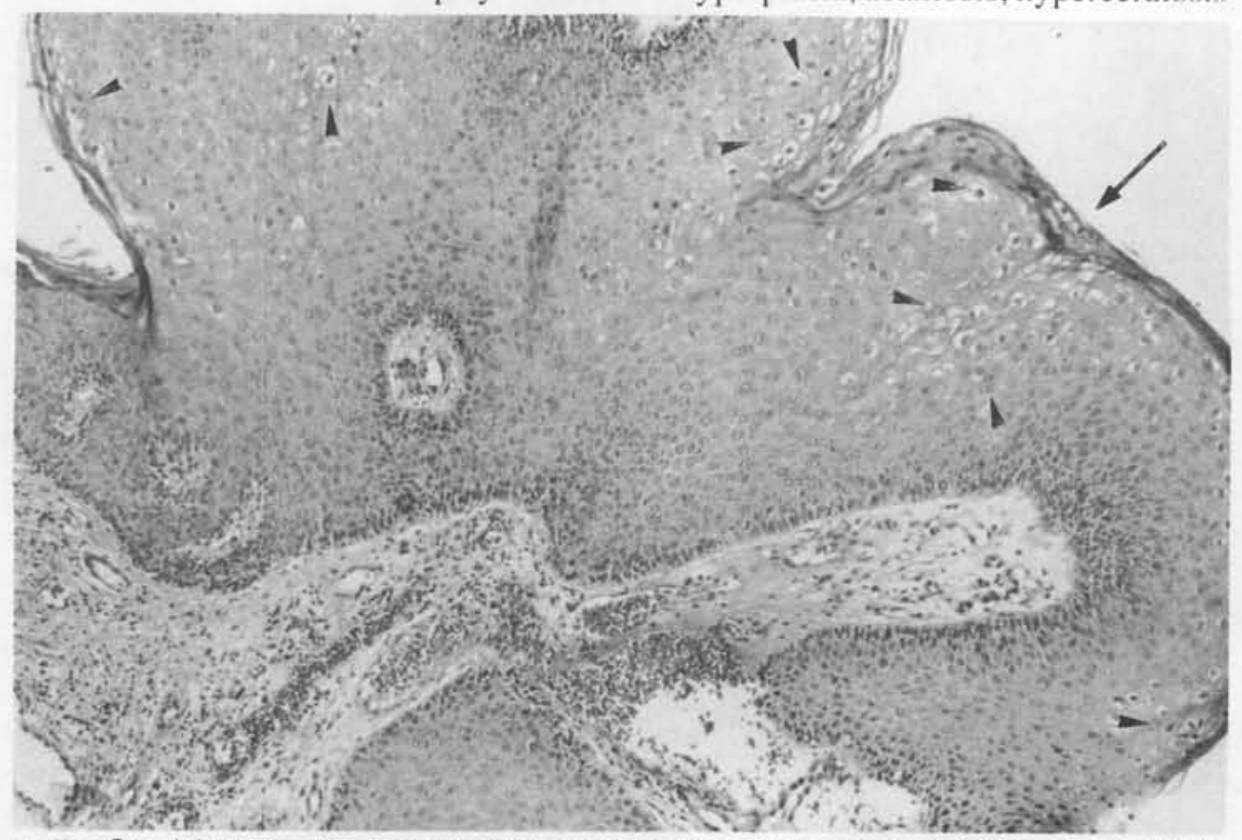

Figure 5 - Condylomata acuminatum with various koilocytosis, representative of the VIRAL REPLICATION ACTIVITY PHASE. (Hematoxilina \& Eosina Objective 10x Ocular 10x). 


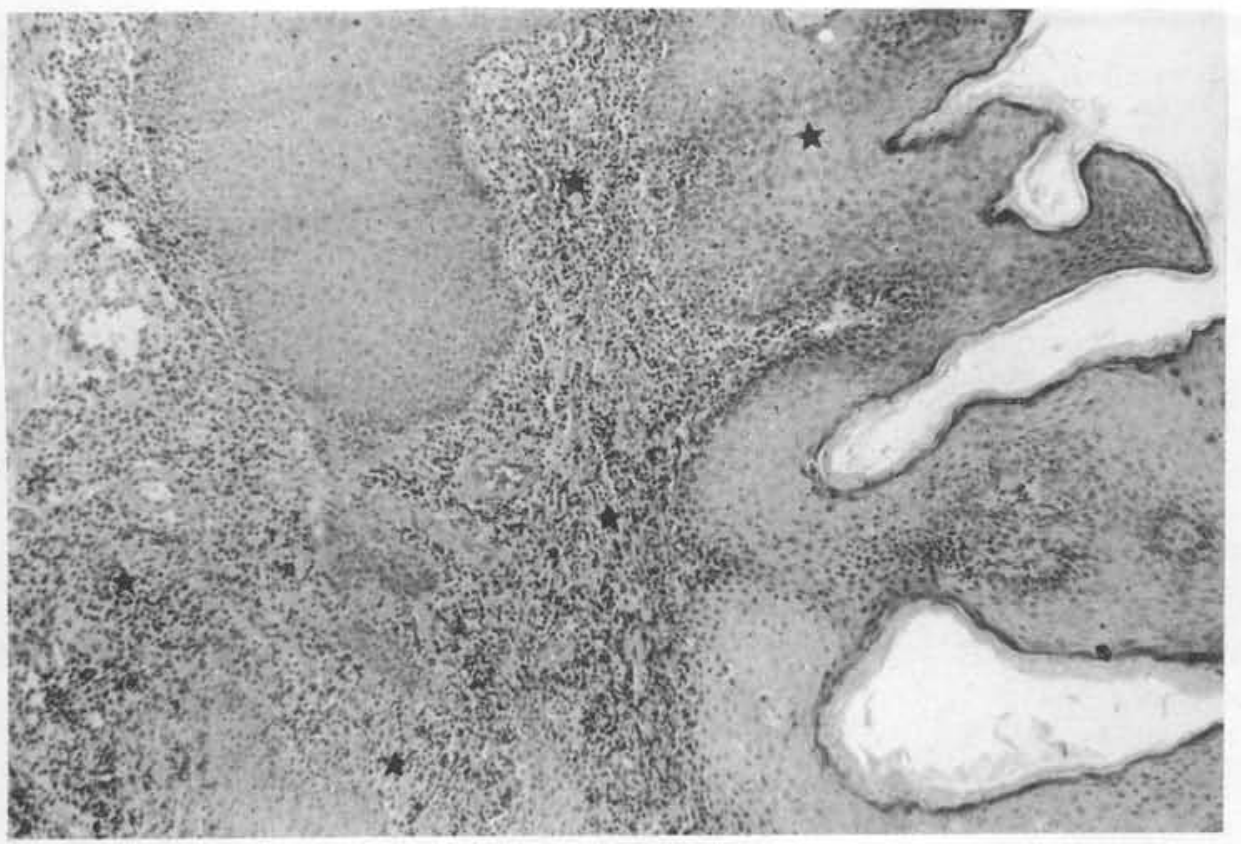

Figure 6 - Condylomata acuminatum with accentuated transepithelial lymphocytic infiltrate without koilocytosis (H), REGRESSIVE PHASE. (Hematoxilina \& Eosina Objective $4 \mathrm{x}$ Ocular $10 \mathrm{x}$ ). koilocytosis in some lesions may explain the negative results observed in studies utilizing procedures such as immunohistochemistry and/ or in situ hybridization with the aim of virus identification. Koilocytosis was diagnosed in accordance with MEISELS ${ }^{6}$ criteria. The presence of a perinuclear halo, even those associated with nuclear alterations, must be carefully interpreted. In our opinion, this can not be regarded as an histopathological criterion of compatibility with HPV infection. Our results have also demonstrated the and paraceratosis in all cases. The paraceratosis was mild in 80 percent and moderate in 20 percent. Koilocytosis was less frequent (17 percent). Mononuclear cell infiltrate was absent in 33 percent, but in the remaining 8 patients mononuclear cell infiltrate was localized in the dermis and classified as mild. This group was considered as Proliferative (P) pattern (Fig.7).

\section{DISCUSSION}

The analyses of specimens from 60 patients with condylomata acuminata shows that there are quantitative histopathological differences among them.

The relatively low incidence observed for koilocytosis (40 percent) was expected as koilocytosis represents the histopathological expression of the cytopathic effect of HPV, and this is evident only in lesions with great viral replication activity. The absence or rarity of importance of koilocytosis in defining a pattern. In 31 cases classified as proliferative or regressive, it was identified in only 8 cases ( 26 percent - Fig. 4 ).

Our study has demonstrated the existence of a group of lesions that show histopathological characteristics that denote a lymphocyte-mediated immunological response by the patient.

The morphological regression phenomena in warts is already well documented not only in animals but also in

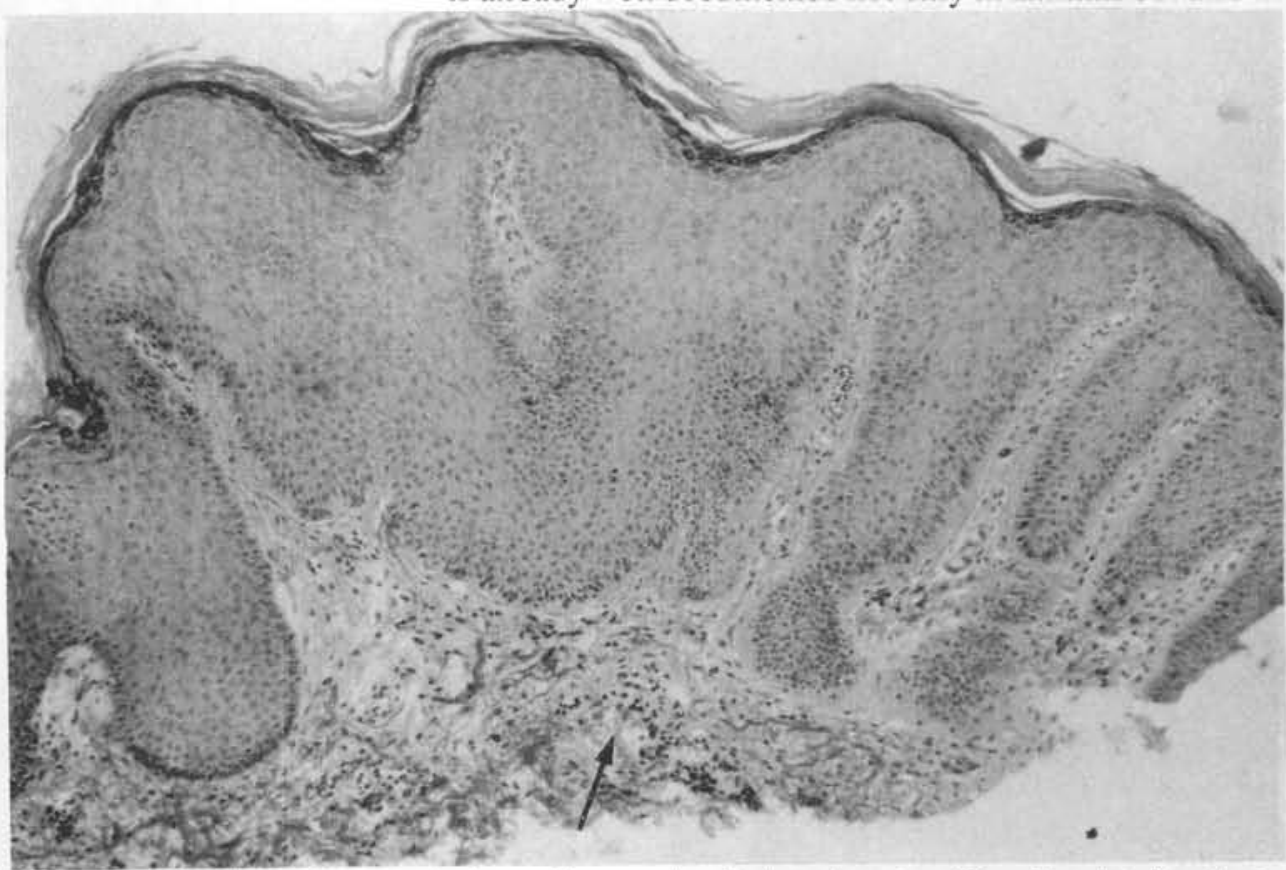

Figure 7 - Condylomata acuminatum with rare dermis lymphocytes (®), without koilocytosis. PROLIFERATIVE PHASE. (Hematoxilina \& Eosina Objective 10x Ocular 10x). 
humans. ${ }^{12-19}$ Our results are in agreement with the literature, contributing to the histopathological characterization of the regression pattern of condylomata acuminata. However, this quantitative study based only in the histopathological analysis is subjective, and its efficacy is questionable.

On the other hand, the distribution of the lymphocytic infiltrate is a more precise criteria which considers only two possibilities: its presence or absence in different sites. We believe that the best histopathological regression marker for condylomata acuminata is the transepithelial localization of the lymphocytic infiltrate.

OKABAYASHI et al., ${ }^{18}$ studying rabbit papillomas, characterized a proliferative phase by a marked epithelial proliferation when compared with the other phases. In our study, we characterized a group of lesions by the absence of koilocytosis and transepithelial lymphocytic infiltrate (Group C). Employing the basal cell hyperplasia criterion - the histopathological expression of proliferation in squamous cell epithelium - we were able to verify its presence in all Group C cases (Fig. 4), and in 25 and 32 percent of group A and B cases, respectively. This expressed difference was a major criteria for classifying Group $C$ as representative of the proliferative pattern which probably corresponds to the early phase of HPV infection.

Acantosis and hyperceratosis were present in all cases and for this reason they were not considered as particular criteria for any group. Paraceratosis was also observed in all cases. However, it was inconspicuous in the proliferative pattern and marked in the activity pattern, showing a clear relationship between the cytopathic effect of HPV and the disturbance in squamous cell differentiation (Fig. 4).

Prior studies have primarily emphasized the clinical variations of condylomata acuminata, and secondarily the identification of the virus by different technological methods based on immunopathology and molecular biology. $2.3,7.8$

Our study resulted in three distinct patterns of condyloma cuminatum: proliferative, viral replication activity and regressive. These patterns probably reflect the biological phase of the HPV infection: one phase of interference in the control of epithelium proliferation, another phase of an intense viral replication with cytopathic effects expression and finally, a phase characterized by the regression of the action of the HPV, possibly in answer to the host defense.

These biological phases are probably linked to the clinical expression phases. However, it is possible that the duration of each phase depends on an efficient immune response. An accurate histopathologic study of condyloma acuminatum, besides improving the precise diagnosis of lesions not presenting koilocytosis, permits the identification of the histopathological pattern. The correlation of this pattern with the evolution time of the lesion and the recurrence history could give the physician a prognostic evaluation based on the patient's own current defenses.

\section{Resumo}

O condiloma acuminado corresponde à uma das manifestaçōes clinicas da infecção pelo Papilomavirus humano. Os aspectos histopatológicos clássicos sāo reconhecidos de longa data e não constituem problema diagnóstico. Clinicamente, já estāo bem caracterizadas as fases de crescimento, de plenitude da expressāo clínica e regressiva ou persistente. Os aspectos histopatológicos destas fases foram documentadas em papilomas eqüinos. Formulamos um protocolo de análise histopatológica para investigar a possibilidade de identificação das fases evolutivas em condilomas acuminados genitais. Foram estudados 60 condilomas acuminados, examinados no Serviço de Anatomia Patológica do Hospital Universitário Antonio Pedro (HUAP). Todos os casos foram revistos, avaliando-se a presença de coilocitose, hiperceratose, paraceratose, acantose, hiperplasia da basal e infiltrado inflamatório mononuclear. Após a análise individual e comparativa dos casos, identificou-se como principais aspectos diferenciais entre os vários condilomas acuminados a coilocitose, o infiltrado linfocitário transepitelial e a hiperplasia da basal. Os condilomas podem ser distinguidos, histopatologicamente, em três padrōes principais: proliferativo, de atividade de replicação virótica e regressivo. 


\section{REFERENCES}

1. Ferenczy A. Epidemiology and clinical pathophysiology of condylomata acuminata. Am J Obstet Gynecol 1995;172:1331-39.

2. Oriel JD. Natural history of genital warts. Brit J Vener Dis 1971;47:1-13.

3. Sykes NL. Condyloma acuminatum. Int J Dermtol 1995;34:297-302.

4. Schneider A. Pathogenesis of genital HPV infection. Genitourin Med 1993;69:165-73.

5. Dias EP, Barcelos JMP, Fonseca MEF, Basso NGS. Congenital papillomas and papillomatosis associated with the HPV - Report on 5 cases. São Paulo Med J 1995;113: 957-63.

6. Meisels A, Fortin R, Roy M. Condylomatous Lesions of the Cervix II: a cytologic, colposcopic and histopathologic study. Acta Cytologica 1977;21:379-89.

7. Dias EP. Papilomavírus humano - Aspectos biológicos, clínicos e morfológicos. JBM 1993;64:206-17.

8. Myint SH, Shaw AV. Laboratory identification of human papillomavirus infection. In: Eds., Mindel A, Arnold E. Genital Warts human papillomavirus infection. London, 1995:35-52.

9. Rock B, Shah K, Farmer E. A morphologic, pathologic, and virologic study of anogenital warts in men. Arch Dermatol 1992;127:495-500.

10. Gross G, Ikenberg H, Gissmann L, Hasedorn M. Papillomavirus infection of the anogenital region: Correlation between histology, clinical picture and virus type - Proposal of a new nomenclature. J Invest Dermatol 1985;85:147-52.

11. Hamada M, Oyamada T, Yoshikawa H, Yoshikawa T, Itakura C. Histopathological development of equine cutaneous papillomas. J Comp Pathol 1990;102(4:393-403.

12. Tagami H, Ogino A, Takigawa M, et al. Regression of plane warts following spontaneous inflamation: A histopathological study. Br J Dermatol 1974;90:147-54.

13. Tagami H, Takigawa M, Ogino A, Imamura S, Ofugi S. Spontaneous regression of plane warts after inflammation. Arch Dermatol 1977;113:1209-13.

14. Tagami H, Oguchi M, Ofuji S. The phenomenon of spontaneous regression of numerous flat warts: Immunological studies. Cancer 1980;45:2557-63.

15. Aiba S, Rokugo M, Tagami H. Immunohistọlogic analysis of the phenomenon of spontaneous regression of numerous flat warts. Cancer 1986;58:1246-51.

16. Bishop PE, Millan AMc, Fletcher S. An immunohistological study of spontaneous regression of condylomata acuminata. Genitourin Med 1990;66:79-81.

17. Stanley MA, Chambers MA, Coleman N. Immunology of human papilomavirus infection. In: Eds., Mindel A, Arnold E. Genital Warts human papillomavirus infection. London, 1995:259.

18. Okabayashi M, Angell MG, Budgeon LR, Kreider JW. Shope papilloma cell and leukocyte proliferation in regressing and progressing lesions. Am J Pathol 1993;142:489-95.

19. Coleman N, Birley HDL, et al. Immunological events in regressing genital warts. Am J Clin Pathol 1994;102:768-74. 